\title{
EFFECT OF STORAGE TIME ON FISH FEED STORED AT ROOM TEMPERATURE AND LOW TEMPERATURE
}

\author{
M. N. Hossen, M. Das, K. R. Sumi* and M. T. Hasan \\ Department of Aquaculture, Bangladesh Agricultural University \\ Mymensingh-2202, Bangladesh
}

\begin{abstract}
An experiment was conducted to determine the changes of nutritive value of different commercial fish feeds stored at room temperature $\left(25-30^{\circ} \mathrm{C}\right)$ and low temperature $\left(5-8^{\circ} \mathrm{C}\right)$ for a period of two months by taking biweekly sample. Three most popular fish feeds named Mega fish feed, Quality fish feed and Saudi Bangla fish feed used in the Mymensingh region were selected for the purpose. Throughout the study, physical characteristics and proximate composition of three commercial fish feeds were analyzed. There were no change in color, appearance of moderately bad odour, a little bit of soft texture and broken pellets were found in later stages of the experiment but the overall quality was still acceptable. Along with physical characteristics, changes were occurred in case of proximate composition. In Mega, Quality and Saudi Bangla fish feed, crude protein content was reduced in both the storage conditions. Lipid content also exhibited similar reduction due to storage at both the conditions. Whereas moisture content increased a little bit in the case of room temperature storage and decreased when stored in low temperature $\left(5-8^{\circ} \mathrm{C}\right)$. No marked changes had been occurred in other proximate composition like ash, and crude fibre. Declining rate of the quality of fish feeds was higher at room temperature $\left(25-30^{\circ} \mathrm{C}\right)$ than low temperature $\left(5-8^{\circ} \mathrm{C}\right)$ but the overall quality remained acceptable upto two months storage at both the conditions. It is suggested to use the feed within two months after manufacture.
\end{abstract}

Key Words: Fish feed, Storage, Room temperature, Low temperature

\section{INTRODUCTION}

With the increasing demand for food fish and the decline in capture fisheries production, aquaculture in Bangladesh is heading towards intensification. The demand of fish feed is increasing with the intensification of culture. Feed cost generally constitutes the highest single operation cost of semi-intensive or intensive grow-out farming operation (Shang and Costa-Pierce, 1983). Different feed mills and industries produce commercial fish feeds of different protein levels which are used in fish farms. Those industries not only

*Corresponding author: sumi.02bau@gmail.com 
manufacture fish feed but they also produce livestock feed such as poultry, cattle, pet animal etc. On the other hand, hundreds of small-scale non-commercial and on-farm feed mills produce fish feed throughout the country. Still, the demand and supply do not match and farmers always face scarcity of feed. Therefore, establishment of more fish feed industries are urgently needed in our country. On the other hand, some of the industries passing lean period of feed demand and their capacity are not being utilized for the production of feed.

Fish feed plays an important role in production of fish at a satisfactory level. It is also necessary to meet seasonal peak supply and to increase shelf-life of fish feed so that feed produced during lean period can be supplied during peak period. If it is not stored properly then some microbial and environmental alteration will occur. Farmers buy commercial feed stored for different period of time before reaching them but they don't know the nutritive value of different stored feed. Therefore, it is an urgent need to assess the actual nutritive value of the commercial stored fish feeds available to the farmers. Moreover fish feed naturally undergo various chemical and enzymatic reactions and thus to a large extent to determine their acceptability, shelf life and safety due to factors such as the oxidation of unsaturated lipids, high moisture content and other factors (Kolapo and Sanni, 2007).

A measurable amount of nutritive value of fish feed is decreased in case of storage condition and miller can face an unwanted condition for off season production of fish feed. So the present study was undertaken to assess the changes and compare the nutritive value of different fish feed stored at room temperature and low temperature.

\section{MATERIALS AND METHODS}

The experiment on the quality assessment of fish feed was conducted for the period of two months from July to August, 2011. Mega fish feed, Quality fish feed and Saudi-Bangla fish feed were used in this study. Feeds were collected directly from dealer of those feeds. After collection of feed samples, the samples were stored at room temperature and cool condition $\left(5-8^{\circ} \mathrm{C}\right)$ in store room and were analyzed for physical characteristics and proximate composition.

Bag made of poly-propylene and polythene bag were used to store fish feed. To store in refrigeration temperature polythene bags were used. During storage condition, room temperature was varied from 25 to $30^{\circ} \mathrm{C}$ and low temperature (cool condition) was ranged from 5 to $8^{\circ} \mathrm{C}$. The feed thus stored were sampled for analysis at 15 days interval.

In the case of samples stored in low temperature were taken from the refrigerator and kept in ambient temperature for few hours before proximate composition analysis. Then the required amounts of samples were finely ground by a grinding machine and kept in airtight packet for subsequent chemical analysis. The samples stored in room temperature also prepared by the same way. 
Physical characteristics evaluation is easy but rough in nature. One must be highly trained to identify the changes in the nature of the feeds. Sensory organ is most important to analyze the physical and chemical characteristics of fish feed.

The good quality fish feed are shining with good luster and show hardness. The various physical changes of the fish feeds undergo during storage were checked for dull colour, soft texture, rusty odour, bores in feeds and production of fines. Normally the colours of fish feeds of brown; deep brown etc. when alteration of colour indicates the microbial contamination. Odour is the next best indicator just standing near the stock itself will immediately indicate any difference in the normal smell. Broken pieces can be analyzed by sieving. Infestation of insect, microbes, fungi was also checked.

The proximate composition of different commercial fish feeds were analyzed in duplicate following the standard procedure given by Association of Official Analytical Chemists (AOAC, 2000) in the Fish Nutrition Laboratory, Department of Aquaculture, Faculty of Fisheries, Bangladesh Agricultural University, Mymensingh. For the statistical analysis of the data, simple statistics was done by determining the average with standard deviation of the proximate composition data.

\section{RESULTS AND DISCUSSION}

The characteristic colour of Mega, Quality and Saudi Bangla fish feed was brown, deep brown and brown, respectively. At the end of 60 days, there were no changes of colour at room temperature $\left(25-30^{\circ} \mathrm{C}\right)$ and low temperature $\left(5-8^{\circ} \mathrm{C}\right)($ Table 1$)$. At initial stage, the odour of each of the Mega, Quality and Saudi Bangla fish feed possesed characteristic odour. The odour of feed felt somewhat mixed smell of dry fish and mastered oil cake. At the end of 45 days the characteristic odour changed a bit and moderately bad odour sensed at the end of 60 days stored at room temperature $\left(25-30^{\circ} \mathrm{C}\right)$ and also at low temperature $\left(5-8^{\circ} \mathrm{C}\right)$ (Table 1). Odour may change due to increase in moisture and microbial contamination at the later stage of two months storage period.

The texture of Mega, Quality and Saudi Bangla fish feed were found normal pellets of around $1 \mathrm{~cm}$ size and hardy. At the end of 45 days the normal texture of little amount of pellets changed to a bit of soft texture and found some fines at the end of 60 days stored at room temperature and low temperature (Table 1). It may occur for increasing moisture content and improper handling of feeds. Mega, Quality and Saudi Bangla fish feed were not infested at the initial stage of the study. At the end of 60 days feed remains infestation free at room temperature and refrigeration temperature (Table 1). It may occur due to humidity below $70 \%$, controlled temperature below $35-40^{\circ} \mathrm{C}$ and good packaging of feeds. There were no broken pieces found at the initial stage but at the end of 60 days there were a little bit of fines were found stored at room temperature and low temperature (Table 1). This characteristic was found for softening of the texture might be due to increase moisture content of feeds stored at room temperature and auto degradation in case of both the conditions. 
Mega fish feed, Quality fish feed and Saudi Bangla fish feed were highly acceptable upto 45 days storage and after 60 days of storing the overall quality became a bit of soft and offered unpleasant smell signaling the starting of spoilage stored at both the condition (Table 1) still the feed were at acceptable level. De Silva et al. (1995) reported proper flavour and appearance changes during storage and found feeds lump and less palatable when stored. Storage never enhances feed quality, but proper storage reduces the rapidity at which a feed deteriorates.

Table 1. Changes in physical characteristics of Mega fish feed, Quality fish feed and Saudi Bangla fish feed stored at room temperature $\left(25-30^{\circ} \mathrm{C}\right)$ and low temperature $\left(5-8^{\circ} \mathrm{C}\right)$

\begin{tabular}{|c|c|c|c|c|c|c|}
\hline Feeds & $\begin{array}{l}\text { Character } \\
\text {-istics }\end{array}$ & $\begin{array}{l}\text { Initial (within } \\
\text { 2-3 days of } \\
\text { preparation) }\end{array}$ & $\begin{array}{l}\text { After } 15 \text { days } \\
\text { storing }\end{array}$ & $\begin{array}{l}\text { After } 30 \text { days } \\
\text { storing }\end{array}$ & $\begin{array}{l}\text { After } 45 \text { days } \\
\text { storing }\end{array}$ & $\begin{array}{l}\text { After } 60 \text { days } \\
\text { storing }\end{array}$ \\
\hline Mega fish feed & Color & Brown & Brown & Brown & Brown & Brown \\
\hline $\begin{array}{l}\text { Quality fish } \\
\text { feed }\end{array}$ & & Deep brown & Deep brown & Deep brown & Deep brown & Deep brown \\
\hline $\begin{array}{l}\text { Saudi Bangla } \\
\text { fish feed }\end{array}$ & & Brown & Brown & Brown & Brown & Brown \\
\hline Mega fish feed & Odour & $\begin{array}{c}\text { Characteristic } \\
\text { odour }\end{array}$ & $\begin{array}{c}\text { Characteristic } \\
\text { odour }\end{array}$ & $\begin{array}{c}\text { Characteristic } \\
\text { odour }\end{array}$ & $\begin{array}{l}\text { Moderately } \\
\text { bad odour }\end{array}$ & $\begin{array}{l}\text { Moderately bad } \\
\text { odour }\end{array}$ \\
\hline $\begin{array}{l}\text { Quality fish } \\
\text { feed }\end{array}$ & & $\begin{array}{c}\text { Characteristic } \\
\text { odour }\end{array}$ & $\begin{array}{c}\text { Characteristic } \\
\text { odour }\end{array}$ & $\begin{array}{c}\text { Characteristic } \\
\text { odour }\end{array}$ & $\begin{array}{l}\text { Moderately } \\
\text { bad odour }\end{array}$ & $\begin{array}{l}\text { Moderately bad } \\
\text { odour }\end{array}$ \\
\hline $\begin{array}{l}\text { Saudi Bangla } \\
\text { fish feed }\end{array}$ & & $\begin{array}{l}\text { Characteristic } \\
\text { odour }\end{array}$ & $\begin{array}{c}\text { Characteristic } \\
\text { odour }\end{array}$ & $\begin{array}{c}\text { Characteristic } \\
\text { odour }\end{array}$ & $\begin{array}{l}\text { Moderately } \\
\text { bad odour }\end{array}$ & $\begin{array}{c}\text { Moderately bad } \\
\text { odour }\end{array}$ \\
\hline Mega fish feed & Texture & Normal texture & $\begin{array}{l}\text { Normal } \\
\text { texture }\end{array}$ & $\begin{array}{l}\text { Normal } \\
\text { texture }\end{array}$ & $\begin{array}{l}\text { A bit of soft } \\
\text { texture }\end{array}$ & A bit of soft texture \\
\hline $\begin{array}{l}\text { Quality fish } \\
\text { feed }\end{array}$ & & Normal texture & $\begin{array}{l}\text { Normal } \\
\text { texture }\end{array}$ & $\begin{array}{l}\text { Normal } \\
\text { texture }\end{array}$ & $\begin{array}{l}\text { A bit of soft } \\
\text { texture }\end{array}$ & A bit of soft texture \\
\hline $\begin{array}{l}\text { Saudi Bangla } \\
\text { fish feed }\end{array}$ & & Normal texture & $\begin{array}{l}\text { Normal } \\
\text { texture }\end{array}$ & $\begin{array}{l}\text { Normal } \\
\text { texture }\end{array}$ & $\begin{array}{l}\text { A bit of soft } \\
\text { texture }\end{array}$ & A bit of soft texture \\
\hline Mega fish feed & Infestation & No infestation & $\begin{array}{c}\text { No } \\
\text { infestation }\end{array}$ & $\begin{array}{c}\text { No } \\
\text { infestation }\end{array}$ & $\begin{array}{c}\text { No } \\
\text { infestation }\end{array}$ & No infestation \\
\hline $\begin{array}{l}\text { Quality fish } \\
\text { feed }\end{array}$ & & No infestation & $\begin{array}{c}\text { No } \\
\text { infestation }\end{array}$ & $\begin{array}{c}\text { No } \\
\text { infestation }\end{array}$ & $\begin{array}{c}\text { No } \\
\text { infestation }\end{array}$ & No infestation \\
\hline $\begin{array}{l}\text { Saudi Bangla } \\
\text { fish feed }\end{array}$ & & No infestation & $\begin{array}{c}\text { No } \\
\text { infestation }\end{array}$ & $\begin{array}{c}\text { No } \\
\text { infestation }\end{array}$ & $\begin{array}{c}\text { No } \\
\text { infestation }\end{array}$ & No infestation \\
\hline Mega fish feed & Broken & No fines & No fines & No fines & No fines & A little bit of fines \\
\hline $\begin{array}{l}\text { Quality fish } \\
\text { feed }\end{array}$ & $\begin{array}{l}\text { pieces } \\
\text { and fines }\end{array}$ & No fines & No fines & No fines & No fines & A little bit of fines \\
\hline $\begin{array}{l}\text { Saudi Bangla } \\
\text { fish feed }\end{array}$ & & No fines & No fines & No fines & No fines & A little bit of fines \\
\hline Mega fish feed & $\begin{array}{l}\text { Overall } \\
\text { quality }\end{array}$ & Acceptable & Acceptable & Acceptable & Acceptable & $\begin{array}{c}\text { Acceptable but } \\
\text { starting of spoilage } \\
\text { symptom }\end{array}$ \\
\hline $\begin{array}{l}\text { Quality fish } \\
\text { feed }\end{array}$ & & Acceptable & Acceptable & Acceptable & Acceptable & $\begin{array}{c}\text { Acceptable but } \\
\text { starting of spoilage } \\
\text { symptom }\end{array}$ \\
\hline $\begin{array}{l}\text { Saudi Bangla } \\
\text { fish feed }\end{array}$ & & Acceptable & Acceptable & Acceptable & Acceptable & $\begin{array}{c}\text { Acceptable but } \\
\text { starting of spoilage } \\
\text { symptom }\end{array}$ \\
\hline
\end{tabular}


The value of the initial crude protein content in Mega, Quality and Saudi Bangla fish feed were $23.89 \%, 24.70 \%$ and $29.10 \%$, respectively. At the end of 60 days, crude protein content reduced and remained $21.64 \%, 21.29 \%$ and $23.72 \%$, respectively at room temperature and $20.82 \%, 22.44 \%$ and $27.18 \%$, respectively in low temperature (Table 2, Table 3 and Table 4). Mitchell et al. (1949) reported changes in the chemical composition and nutritive value of the feed may occur during storage. The nature and extent of these changes may depend upon the initial condition of the feed, particularly upon its moisture content, and the conditions of storage.

Table 2. Changes in proximate composition (\%) of Mega fish feed stored at room temperature $\left(25-30^{\circ} \mathrm{C}\right)($ Mean $\pm \mathrm{SD})$

\begin{tabular}{l|c|c|c|c|c}
\hline $\begin{array}{c}\text { Proximate } \\
\text { composition } \\
(\%)\end{array}$ & $\begin{array}{c}\text { Initial (within 2-3 } \\
\text { days of } \\
\text { preparation) }\end{array}$ & $\begin{array}{c}15 \text { days } \\
\text { storing }\end{array}$ & $\begin{array}{c}30 \text { days } \\
\text { storing }\end{array}$ & $\begin{array}{c}45 \text { days } \\
\text { storing }\end{array}$ & $\begin{array}{c}60 \text { days } \\
\text { storing }\end{array}$ \\
\hline Protein & $23.89 \pm 0.819$ & $23.31 \pm 0.344$ & $23.01 \pm 0.666$ & $22.25 \pm 0.176$ & $21.64 \pm 0.560$ \\
Lipid & $9.14 \pm 0.507$ & $7.00 \pm 0.565$ & $6.22 \pm 0.099$ & $5.44 \pm 0.173$ & $5.11 \pm 0.254$ \\
& & $(7.42 \pm 0.347)$ & $(6.42 \pm 0.315)$ & $(6.22 \pm 0.096)$ & $(6.09 \pm 0.244)$ \\
Moisture & $11.34 \pm 0.146$ & $11.92 \pm 0.138$ & $11.99 \pm 0.398$ & $12.04 \pm 0.166$ & $11.56 \pm 0.384$ \\
& & $(11.23 \pm 0.080)$ & $(11.43 \pm 0.167)$ & $(11.63 \pm 0.426)$ & $(11.22 \pm 0.278)$ \\
Ash & $16.13 \pm 0.192$ & $16.03 \pm 0.207$ & $15.86 \pm 0.105$ & $15.89 \pm 0.292$ & $16.26 \pm 0.184$ \\
& & $(15.61 \pm 0.321)$ & $(15.71 \pm 0.150)$ & $(15.81 \pm 0.103)$ & $(16.15 \pm 0.125)$ \\
Crude fibre & $5.60 \pm 0.147$ & $5.88 \pm 0.359$ & $5.69 \pm 0.154$ & $5.50 \pm 0.147$ & $4.80 \pm 0.118$ \\
& & $(5.20 \pm 0.085)$ & $(4.82 \pm 0.958)$ & $(4.45 \pm 0.174)$ & $(5.25 \pm 0.269)$ \\
Total nitrogen & $3.82 \pm 0.131$ & $3.73 \pm 0.055$ & $3.68 \pm 0.106$ & $3.56 \pm 0.028$ & $3.46 \pm 0.090$ \\
& & $(3.75 \pm 0.032)$ & $(3.59 \pm 0.027)$ & $(3.45 \pm 0.043)$ & $(3.33 \pm 0.145)$ \\
Nitrogen in & $3.77 \pm 0.128$ & $3.7295 \pm 0.056$ & $3.68 \pm 0.107$ & $3.56 \pm 0.029$ & $3.46 \pm 0.090$ \\
Protein & & $(3.75 \pm 0.032)$ & $(3.59 \pm 0.027)$ & $(3.45 \pm 0.042)$ & $(3.33 \pm 0.145)$ \\
\hline
\end{tabular}

Figure in the parenthesis indicates changes in proximate composition of Mega fish feed stored at low temperature $\left(5-8^{\circ} \mathrm{C}\right)$

The value of the initial lipid content in Mega, Quality and Saudi Bangla fish feed were $9.14 \%, 7.31 \%$ and $9.19 \%$, respectively. At the end of 60 days, lipid content reduced and remained $5.11 \%, 4.90 \%$ and $3.66 \%$, respectively at room temperature and $6.09 \%, 4.91 \%$ and $6.00 \%$, respectively (Table 2, Table 3 and Table 4 ) in low temperature. In this study, it had been observed that during storage condition the lipid content decreased gradually, which may be due to auto oxidation (rancidity). Cockerell et al. (1971) investigated the influence of temperature and relative humidity on the growth of fungi on stored feeds. They found that moulds become active at relative humidities above $70 \%$. Fungal activity is higher at temperature of $\left(35-40^{\circ} \mathrm{C}\right)$ in stored feeds. Fungi may assist in the development of lipid ketonic rancidity and non-enzymatic browning in stored feeds. In the present study, no fungus was found during two months storage at both the conditions. Jones (1987) reported 
the detrimental influence of mould growth in stored feeds reduced nutritional value owing to the loss of dietary lipids, amino acids (especially lysine and arginine) and vitamins by enzymatic digestion.

Table 3. Changes in proximate composition (\%) of Quality fish feed stored at room temperature $\left(25-30^{\circ} \mathrm{C}\right)$

\begin{tabular}{lccccc}
\hline $\begin{array}{c}\text { Proximate } \\
\text { composition } \\
(\%)\end{array}$ & $\begin{array}{c}\text { Initial (within 2-3 } \\
\text { days of } \\
\text { preparation })\end{array}$ & $\begin{array}{c}15 \text { days } \\
\text { storing }\end{array}$ & $\begin{array}{c}30 \text { days } \\
\text { storing }\end{array}$ & $\begin{array}{c}45 \text { days } \\
\text { storing }\end{array}$ & $\begin{array}{c}60 \text { days } \\
\text { storing }\end{array}$ \\
\hline Protein & $24.70 \pm 0.498$ & $23.96 \pm 0.839$ & $22.86 \pm 0.574$ & $21.97 \pm 0.42$ & $21.29 \pm 0.246$ \\
& & $(24.33 \pm 0.175)$ & $(23.45 \pm 0.248)$ & $(22.77 \pm 0.184)$ & $(22.44 \pm 0.186)$ \\
Lipid & $7.31 \pm 0.162$ & $5.92 \pm 0.182$ & $5.70 \pm 0.095$ & $5.48 \pm 0.441$ & $4.90 \pm 0.626$ \\
& & $(5.62 \pm 0.314)$ & $(5.22 \pm 0.208)$ & $(5.03 \pm 0.378)$ & $(4.91 \pm 0.113)$ \\
Moisture & $11.84 \pm 0.226$ & $12.79 \pm 0.613$ & $13.66 \pm 0.518$ & $13.74 \pm 0.727$ & $13.51 \pm 0.123$ \\
& & $(11.60 \pm 0.133)$ & $(11.71 \pm 0.038)$ & $(12.03 \pm 0.480)$ & $(11.69 \pm 0.315)$ \\
Ash & $14.41 \pm 0.388$ & $13.69 \pm 0.195$ & $14.39 \pm 0.307$ & $15.10 \pm 0.438$ & $14.91 \pm 0.088$ \\
& & $(13.31 \pm 0.288)$ & $(13.85 \pm 0.472)$ & $(14.38 \pm 0.230)$ & $(14.89 \pm 0.501)$ \\
Crude fibre & $5.65 \pm 0.497$ & $4.20 \pm 0.181$ & $4.54 \pm 0.193$ & $4.88 \pm 0.106$ & $4.70 \pm 0.121$ \\
& & $(4.85 \pm 0.130)$ & $(4.62 \pm 0.272)$ & $(4.40 \pm 0.234)$ & $(4.84 \pm 0.020)$ \\
Total nitrogen & $3.95 \pm 0.080$ & $3.83 \pm 0.134$ & $3.66 \pm 0.092$ & $3.52 \pm 0.068$ & $3.41 \pm 0.039$ \\
& & $(3.89 \pm 0.028)$ & $(3.75 \pm 0.040)$ & $(3.64 \pm 0.029)$ & $(3.59 \pm 0.030)$ \\
Nitrogen in & $3.92 \pm 0.071$ & $3.83 \pm 0.136$ & $3.66 \pm 0.092$ & $3.51 \pm 0.068$ & $3.40 \pm 0.040$ \\
Protein & & $(3.89 \pm 0.028)$ & $(3.75 \pm 0.040)$ & $(3.64 \pm 0.029)$ & $(3.59 \pm 0.025)$ \\
\hline
\end{tabular}

Figure in the parenthesis indicates changes in proximate composition of Quality fish feed stored at low temperature $\left(5-8^{\circ} \mathrm{C}\right)$

The value of the initial moisture content in Mega, Quality and Saudi Bangla fish feed were $11.34 \%, 11.84 \%$ and $11.96 \%$, respectively. At the end of 60 days, moisture content slowly increased and was found to be $11.56 \%, 13.51 \%$ and $13.26 \%$, respectively when stored at room temperature. In low temperature, it increased a little bit first then reduced to $11.22 \%$, $11.69 \%$ and $10.85 \%$, respectively after 60 days of storage (Table 2, Table 3 and Table 4). It had been observed that during storage under two kinds of packaging condition, (Bag made of poly-propylene and polythene) the moisture content increased a little. The rate of increase in moisture content varied on the basis of storage time, packaging and humidity. The National Research Council (1981) reported that feed stored in an area with high moisture and/or high temperatures will cause per oxidation of the lipid and degradation of vitamins. New (1987) considered that a safe moisture level is that which develops at a relative humidity of about $75 \%$, the feeds must be stored for a shorter time.

The value of the initial ash content of Mega, Quality and Saudi Bangla fish feed were $16.13 \%, 14.41 \%$ and $17.05 \%$, respectively. After 60 days, ash content did not vary significantly at both the conditions (Table 2, Table 3 and Table 4). The minor changes of 
ash content in fish feeds throughout storage period in two storage condition might be due to gradual loss of protein and lipid with storage time. Moisture content also responsible for the changes of ash content.

Table 4. Changes in proximate composition (\%) of Saudi Bangla fish feed stored at room temperature $\left(25-30^{\circ} \mathrm{C}\right)$

\begin{tabular}{l|c|c|c|c|c}
\hline $\begin{array}{c}\text { Proximate } \\
\text { composition } \\
(\%)\end{array}$ & $\begin{array}{c}\text { Initial (within } \\
\text { 2-3 days of } \\
\text { preparation) }\end{array}$ & 15 days storing & 30 days storing & 45 days storing & 60 days storing \\
\hline Protein & $29.10 \pm 0.240$ & $26.99 \pm 0.356$ & $25.70 \pm 0.253$ & $24.80 \pm 0.123$ & $23.72 \pm 0.077$ \\
& & $(28.66 \pm 0.199)$ & $(28.29 \pm 0.161)$ & $(27.93 \pm 0.312)$ & $(27.18 \pm 0.164)$ \\
Lipid & $9.19 \pm 0.202$ & $8.08 \pm 0.064$ & $5.98 \pm 0.202$ & $3.88 \pm 0.170$ & $3.66 \pm 0.122$ \\
& & $(7.71 \pm 0.128)$ & $(6.85 \pm 0.152)$ & $(6.19 \pm 0.166)$ & $(6.00 \pm 0.308)$ \\
Moisture & $11.96 \pm 0.219$ & $12.58 \pm 0.302$ & $13.33 \pm 0.277$ & $13.88 \pm 0.172$ & $13.26 \pm 0.133$ \\
& & $(10.54 \pm 0.092)$ & $(10.89 \pm 0.353)$ & $(11.24 \pm 0.221)$ & $(10.85 \pm 0.064)$ \\
Ash & $17.05 \pm 0.071$ & $16.87 \pm 0.230$ & $17.68 \pm 0.106$ & $18.28 \pm 0.258$ & $17.13 \pm 0.189$ \\
& & $(17.16 \pm 0.069)$ & $(17.65 \pm 0.270)$ & $(18.14 \pm 0.123)$ & $(17.62 \pm 0.067)$ \\
Crude fibre & $6.15 \pm 0.161$ & $5.98 \pm 0.330$ & $6.16 \pm 0.121$ & $6.34 \pm 0.066$ & $5.90 \pm 0.101$ \\
& & $(5.95 \pm 0.147)$ & $(6.05 \pm 0.193)$ & $(6.15 \pm 0.128)$ & $(6.15 \pm 0.128)$ \\
Total nitrogen & $4.66 \pm 0.038$ & $4.32 \pm 0.057$ & $4.11 \pm 0.041$ & $3.97 \pm 0.020$ & $3.80 \pm 0.012$ \\
& & $(4.59 \pm 0.032)$ & $(4.53 \pm 0.026)$ & $(4.47 \pm 0.050)$ & $(4.35 \pm 0.026)$ \\
Nitrogen in & $4.59 \pm 0.044$ & $4.32 \pm 0.057$ & $4.11 \pm 0.041$ & $3.97 \pm 0.020$ & $3.79 \pm 0.012$ \\
Protein & & $(4.58 \pm 0.032)$ & $(4.53 \pm 0.026)$ & $(4.47 \pm 0.050)$ & $(4.35 \pm 0.026)$ \\
\hline
\end{tabular}

Figure in the parenthesis indicates changes in proximate composition of Saudi Bangla fish feed stored at low temperature $\left(5-8^{\circ} \mathrm{C}\right)$

The value of the initial crude fibre content of Mega, Quality and Saudi Bangla fish feed were $5.60 \%, 5.65 \%$ and $6.15 \%$, respectively. No particular trend of changing of crude fibre content was found in most cases but it was reduced at the end of the experiment in one case when stored at low temperature (Table 2, Table 3 and Table 4). The changes of crude fibre content occured due to changes of other proximate composition such as crude protein, crude lipid, ash and also due to microbial contamination.

The value of the initial total nitrogen content in Mega, Quality and Saudi Bangla fish feed were $3.82 \%, 3.95 \%$ and $4.66 \%$, respectively. At the end of 60 days, it reduced to $3.46 \%$, $3.41 \%$ and $3.80 \%$, respectively when stored at room temperature and $3.33 \%, 3.59 \%$ and $4.35 \%$, respectively (Table 2, Table 3 and Table 4 ) when stored at low temperature. The total nitrogen content gradually decreased with the time of storage. Nitrogen might had been escaped from the feed in the form of $\mathrm{NH}_{4}$ or other volatile compounds.

In the present experiment, the proper storage condition was maintained but it was observed that quality degradation of feeds had been occurred for both the conditions 
during the storage of two months. Declining rate of the quality of feeds was a little bit higher at room temperature $(25-30)^{\circ} \mathrm{C}$ than at low temperature $(5-8)^{\circ} \mathrm{C}$. Carefully controlled storage condition should be maintained for increasing the shelf life of feeds. Therefore, it can be forcefully stated that the storage condition neither enhance the feed quality nor conserve the original quality perfect, but proper storage reduce the rapidity of feed deterioration. From the results obtained it can be said that the feed of aforesaid companies should not be stored more than two months either at room temperature or at low temperature. Therefore, it is recommended that the prepared feed should not be stored more than two months either in the factory store or at the farmers store. The feeds should be used feed before two months of manufacturing date.

\section{REFERENCES}

AOAC, 2000. Official methods of Analysis. 17th edn. Association of Official Analytical Chemist, Washington DC. 2200 pp.

Cockerell I., Francis, B. and Halliday, D. 1971. Changes in nutritive value of concentrate feedstuffs during storage. Proceeding of the Conference on Development of Feed Resources and Improvement of Animal Feeding Methods in the CENTO Region Countries, Tropical Products Institute, London. pp. 181-192.

De Silva, S. S. and Anderson, T. A. 1995. Fish Nutrition in Aquaculture. Chapman \& Hall, New York, Tokyo, London. 319 pp.

Jones, F. 1987. Controlling mould growth in feeds. Feed Int., 8: 20-29.

Kolapo A. L. and Sanni M. O. 2007. Biochemical changes of soyiru (fermented soybean) during storage. Agricultural and Food Science Journal of Ghana, 6: 471 - 483.

Mitchell, H. H. and Beadles, J. R. 1949. The Effect of Storage on the Nutritional Qualities of the Proteins of Wheat, Corn And Soybeans. University of Illinois, Urbana, Division of Animal Nutrition. pp. 463-484.

National Research Council, 1981. Nutrient Requirements of Coldwater Fishes. National Academy of Sciences, Washington DC. 63 pp.

New, M. B. 1987 Feeds and feeding of fish and shrimp: a manual on the preparation and presentation of compound feeds for fish and shrimp in aquaculture. FAO Report No. $\mathrm{ADCP} / \mathrm{REP} / 87 / 26$. Rome. 275 pp.

Shang, Y. C. and Costa-Pierce, B. A. 1983. Integrated aquaculture-agriculture farming systems, some economic aspects. J. World Maricult. Soc., 14: 523-530. 